\title{
PHARMACOECONOMIC ANALYSIS OF ANTIBACTERIAL MEDICINES USED IN DENTISTRY
}

\author{
M.M.Boyko, O.I.Zaytsev, L.V.Nefyodova, L.V.Iakovlieva
}

\author{
National University of Pharmacy \\ Key words: pharmacoeconomic analysis; synthetic and natural dental medicines
}

\begin{abstract}
This article presents data on pharmacoeconomic analysis of 15 antimicrobial medicines, which are used in dentistry. In order to conduct this analysis the method of estimation of drug antimicrobial properties has been suggested and applied; it is based on vector algebra that allowed calculating a complex indicator of the drug antimicrobial activity for quantitative estimation of the pharmacological effect. It has been shown that the tincture of Sophora japonica and the solution of chlorhexidine digluconate have the best indicators of antimicrobial properties and the lowest treatment cost among the medicines studied at the level of 5-10 UAH. The second group of medicines - "Sanguiritrin" and "Chlorophillipt" (Galichpharm) is as good as the first one in terms of antimicrobial properties, but the course of treatment with these medicines costs up to 30-40 UAH. The third group of medicines - "Metrogyl Denta", the tincture of eucalyptus - exhibits antimicrobial properties of a medium potency and their cost for the treatment course is in the range of 10-20 UAH. The forth group of medicines"Rotokan", "Romazulan", the tincture of calendula and the tincture of propolis - exhibits the weak antimicrobial properties and has a relatively low cost of treatment in the range of 5-20 UAH. The fifth group of medicines - "Stomatofit", "Orasept", "Hexoral", "Fitodent", and "Kamistad" - exhibits the weakest antimicrobial properties and has the most expensive course of treatment in the range of 40-80 UAH. It has been noted that some of the medicines studied have impractical volume since up to half of the pack is left after finishing the course of treatment. Therefore, we can recommend manufacturers to reduce the drug quantity in the pack by 30-50\% for consumer's convenience.
\end{abstract}

t presenta problem of den-

Atal diseases (periodontitis, stomatitis, gingivitis, etc.) and their treatment is the issue of importance for both Ukraine and the world in general $[6,7]$. One of the main causes of these diseases are microorganisms, which inhabit the oral cavity and are activated in case of unhealthy diet, immunosuppressive conditions of the organism, periodontal injuries or as a consequence of infectious diseases, etc. That is why the treatment is aimed not only at suppressing inflammation and relieving pain, but also at these microorganisms themselves $[8,9,11,12]$.

Some of commonly used medicines for treating periodontitis, stomatitis, and gingivitis are antimicrobial medicines of synthetic and natural (mostly phytogenic) origin $[10,13,14-16]$.

The aim of this paper is to conduct pharmacoeconomic analysis of antimicrobial medicines used in dentistry for treatment of periodontal diseases. In order to do this, it was necessary to examine antimicrobial properties of medicines, to develop the method of estimation of the complex indicator of the drug antimicrobial activity and to conduct pharmacoeconomic analysis on its basis.

\section{Materials and Methods}

For the purpose of screening of antimicrobial properties the following medicines were taken - the tincture of Sophora japonica, the tincture of eucalyptus, the tincture of propolis, the tincture of calendula, "Fitodent", "Stomatofit", "Rotokan", "Romazulan", "Sanguiritrin", "Chlorophillipt" ("Galichpharm" JSC), "Kamistad", "Chlorhexidine digluconate", "Orasept", "Hexoral" and "Metrogyl Denta".

The antimicrobial activity of medicines was determined by the method of "wells" easily performed [2] with determination of diameters of the microorganisms growth inhibition zones [1]. According to recommendations of the $\mathrm{WHO}$ and SPhU (State Pharmacopoeia of Ukraine) the following test strains of microorganisms were used to

M.M.Boyko - Candidate of Pharmacy, teaching assistant of the Department of Processes and Apparatuses of Chemical and Pharmaceutical Manufactures of the National University of Pharmacy (Kharkiv)

estimate the antimicrobial activity of medicines: Staphylococcus aureus ATCC 25923, Escherichia coli ATCC 25922, Pseudomonas aeruginosa ATCC 27853, Proteus vulgaris ATCC 4636, Bacillus subtilis ATCC 6633, Candida albicans ATCC 885/653 [5]. The antimicrobial properties of medicines were examined in the Institute of Microbiology and Immunology State Institution named after I.I. Mechnikov of National Academy of Medical Sciences of Ukraine, Kharkov, under the supervision of the head of the laboratory of Biochemistry of Microorganisms and Nutrient Media, Candidate of Biology, Osolodchenko, T.P.

Statistical processing of the results was conducted in accordance with Article "Statistical analysis of chemical experiment results" of the State Pharmacopoeia of Ukraine [3] with the help of the add-on "Data analysis" of MS Excel 2013 package. The zone diameters of microorganisms growth inhibition were measured using a measuring bar with the measurement error of $\pm 0.1 \mathrm{~mm}$. Assuming that the variation of diameters of microorganism growth inhibition zones oc- 


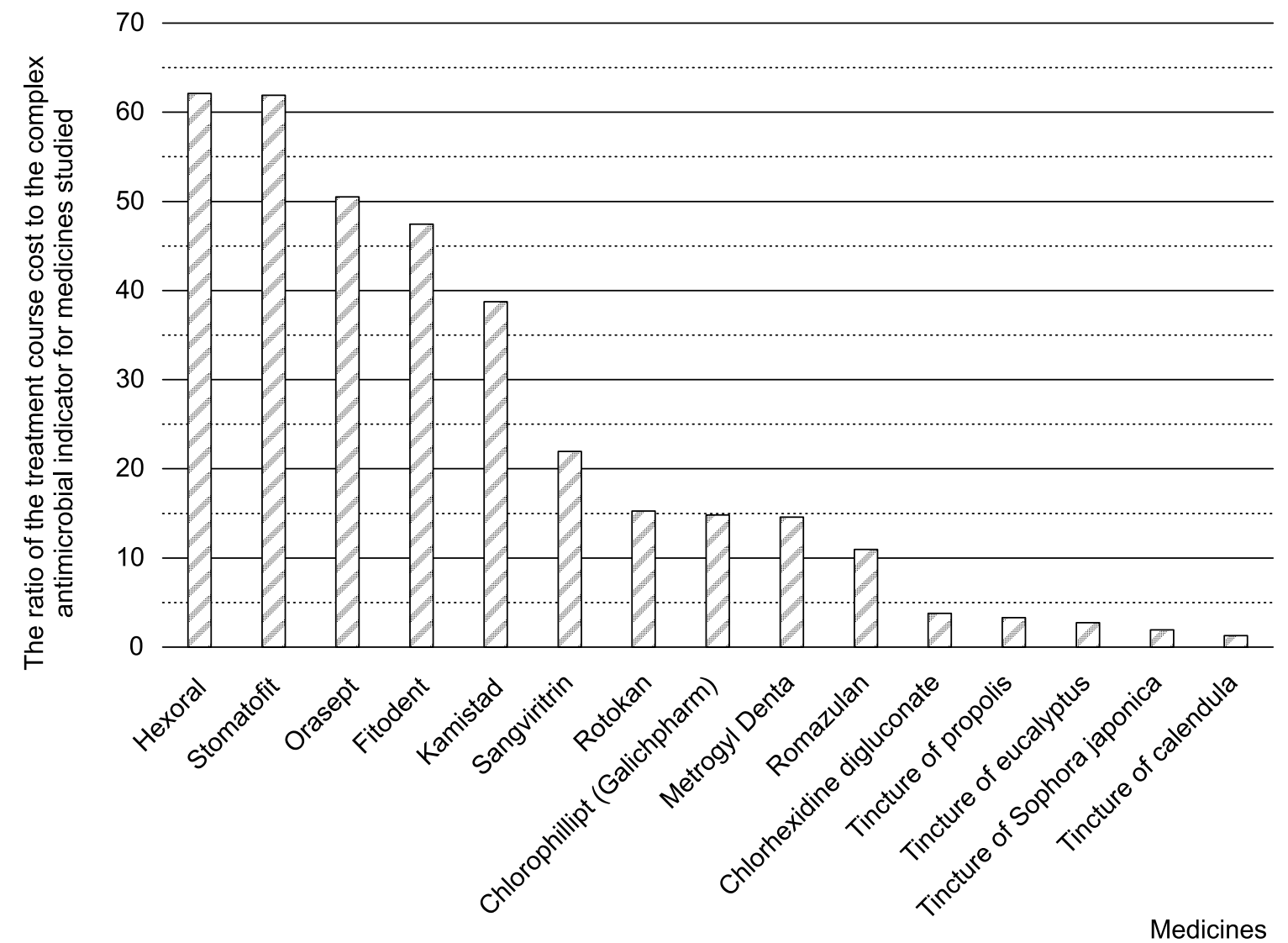

Fig. 1. The ratio of the treatment course cost to the complex antimicrobial indicator for medicines studied

curs by the normal law of distribution, calculation of an average arithmetic diameter and its measurement error were determined with the help of correction for small samples using the Student criterion with the confidence level of 0.95 and the number of degrees of freedom of 5 .

In order to calculate the complex indicator of the drug antimicrobial activity the method of vector algebra was used.

Calculation of the complex indicator of the drug antimicrobial activity and its measurement error was performed using the following formulas:

$$
\begin{aligned}
& A=\left[\left(a_{1} \cdot \frac{D_{1}}{25}\right)^{2}+\left(a_{2} \cdot \frac{D_{2}}{25}\right)^{2}+\right. \\
& +\left(a_{3} \cdot \frac{D_{3}}{25}\right)^{2}+\left(a_{4} \cdot \frac{D_{4}}{25}\right)^{2}+ \\
& \left.+\left(a_{5} \cdot \frac{D_{5}}{25}\right)^{2}+\left(a_{6} \cdot \frac{D_{6}}{25}\right)^{2}\right]^{\frac{1}{2}}
\end{aligned}
$$

and

$$
\begin{aligned}
& \Delta A=\left[a_{1} \cdot\left(\frac{\Delta D_{1}}{25}\right)^{2}+a_{2} \cdot\left(\frac{\Delta D_{2}}{25}\right)^{2}+\right. \\
& +a_{3} \cdot\left(\frac{\Delta D_{3}}{25}\right)^{2}+a_{4} \cdot\left(\frac{\Delta D_{4}}{25}\right)^{2}+ \\
& \left.+a_{5} \cdot\left(\frac{\Delta D_{5}}{25}\right)^{2}+a_{6} \cdot\left(\frac{\Delta D_{6}}{25}\right)^{2}\right]^{\frac{1}{2}},
\end{aligned}
$$

where: $A$ is the complex indicator of the drug antimicrobial activity, dimensionless value, (the indicator efficiency ranges are: 1.0-1.5 the medicine has a weak antimicrobial activity; $1.5-2.5$ - the medicine has a medium antimicrobial activity; more than 2.5 - the medicine has a strong antimicrobial activity);

$a_{1}, a_{2}, a_{3}, a_{4}, a_{5}, a_{6}$ are weighing coefficients of the microorganism strain significance in the disease, in order to simplify we have taken them as a unit, however, application data from research on prevalence degree of microorganisms in affected people can be used [15];
$D_{1}, D_{2}, D_{3}, D_{4}, D_{5}, D_{6}$ are the zone diameters of the growth inhibition of the microorganism strains under research: Staphylococcus aureus ATCC 25923, Escherichia coli ATCC 25922, Pseudomonas aeruginosa ATCC 27853, Proteus vulgaris ATCC 4636, Bacillus subtilis ATCC 6633, Candida albicans ATCC 885/653, mm;

$\Delta A$ is a measurement error of the complex indicator of the drug antimicrobial activity.

The cost of the course of treatment has been calculated using data from the package inserts, assuming that the course of treatment can take an average of $10 \pm$ 4 days [4]. The cost of medicines is given on average from data of Kharkov pharmacies as of September, 2013.

\section{Results and Discussion}

Data on numerical values of the complex indicator of the antimicrobial activity of medicines, as well as other economic indicators are summarized in Table. 


\section{Pharmacoeconomic indicators of antibacterial medicines}

\begin{tabular}{|c|c|c|c|c|c|c|}
\hline No. & $\begin{array}{l}\text { Name of the } \\
\text { medicine }\end{array}$ & $\begin{array}{l}\text { Complex } \\
\text { indicator } \\
\text { of the drug } \\
\text { antimicrobial } \\
\text { activity } \\
\mathrm{A} \pm \Delta \mathrm{A}\end{array}$ & $\begin{array}{l}\text { Price of the } \\
\text { medicine, } \\
\text { UAH / Net } \\
\text { volume or } \\
\text { weight, ml (g) }\end{array}$ & $\begin{array}{l}\text { Unit price of } \\
\text { the medicine, } \\
\text { UAH /ml } \\
(\mathrm{UAH} / \mathrm{g})\end{array}$ & $\begin{array}{c}\text { Volume of the } \\
\text { medicine per the } \\
\text { course of treatment, } \\
\mathrm{ml} \text { or }(\mathrm{g}) / \text { (the } \\
\text { number of entire } \\
\text { packs, p) }\end{array}$ & $\begin{array}{l}\text { Cost of the course } \\
\text { of treatment, } \\
\text { UAH / (the same } \\
\text { according to the } \\
\text { number of entire } \\
\text { packs, UAH) }\end{array}$ \\
\hline 1 & $\begin{array}{l}\text { Chlorhexidine } \\
\text { digluconate }\end{array}$ & $2.07 \pm 0.03$ & $3.90 / 100$ & 0.039 & $\begin{array}{c}200 \pm 80 / \\
(2 \pm 1 \mathrm{p})\end{array}$ & $\begin{array}{l}7.80 \pm 3.12 / \\
(7.80 \pm 3.90)\end{array}$ \\
\hline 2 & Metrogyl Denta & $1.51 \pm 0.06$ & $22.01 /(20)$ & (1.10) & $\begin{array}{c}(10 \pm 4) / \\
(1 \mathrm{p})\end{array}$ & $\begin{array}{c}11.00 \pm 4.40 / \\
(22.01)\end{array}$ \\
\hline 3 & Hexoral & $1.12 \pm 0.03$ & $34.79 / 200$ & 0.174 & $\begin{array}{c}300 \pm 120 / \\
(2 \pm 1 \mathrm{p})\end{array}$ & $\begin{array}{l}52.20 \pm 20.88 / \\
(69.58 \pm 34.79) \\
\end{array}$ \\
\hline 4 & Orasept & $1.09 \pm 0.03$ & $55.07 / 177$ & 0.311 & $\begin{array}{c}111 \pm 45 / \\
(1 \mathrm{p}) \\
\end{array}$ & $\begin{array}{c}34.52 \pm 14.00 / \\
(55.07)\end{array}$ \\
\hline 5 & $\begin{array}{l}\text { Chlorophillipt } \\
\text { (Galichpharm) }\end{array}$ & $1.99 \pm 0.07$ & $14.75 / 100$ & 0.148 & $\begin{array}{c}150 \pm 60 / \\
(2 \pm 1 \mathrm{p}) \\
\end{array}$ & $\begin{array}{c}22.20 \pm 8.88 / \\
(29.50 \pm 14.75) \\
\end{array}$ \\
\hline 6 & Sanguiritrin & $1.91 \pm 0.06$ & $41.95 / 50$ & 0.839 & $\begin{array}{l}50 \pm 20 / \\
(1-2 p) \\
\end{array}$ & $\begin{array}{l}41.95 \pm 16.78 / \\
(41.95 \div 83.90) \\
\end{array}$ \\
\hline 7 & Romazulan & $1.24 \pm 0.04$ & $13.60 / 50$ & 0.272 & $\begin{array}{c}25 \pm 10 / \\
(1 p)\end{array}$ & $\begin{array}{c}6.80 \pm 2.72 / \\
(13.60) \\
\end{array}$ \\
\hline 8 & Kamistad & $1.01 \pm 0.03$ & $39.15 /(10)$ & (3.92) & $\begin{array}{c}(2 \pm 0,8) / \\
(1 \mathrm{p})\end{array}$ & $\begin{array}{c}7.84 \pm 3.14 / \\
(39.15)\end{array}$ \\
\hline 9 & Rotokan & $1.36 \pm 0.06$ & $20.75 / 55$ & 0.377 & $\begin{array}{l}50 \pm 20 / \\
(1-2 p)\end{array}$ & $\begin{array}{c}18.85 \pm 7.54 / \\
(20.75 \div 41.50)\end{array}$ \\
\hline 10 & Stomatofit & $1.20 \pm 0.05$ & $37.15 / 50$ & 0.743 & $\begin{array}{c}100 \pm 40 / \\
(2 \pm 1 \mathrm{p})\end{array}$ & $\begin{array}{l}74.30 \pm 29.72 / \\
(74.30 \pm 37.15) \\
\end{array}$ \\
\hline 11 & Fitodent & $1.06 \pm 0.03$ & $25.15 / 100$ & 0.252 & $\begin{array}{c}150 \pm 60 / \\
(2 \pm 1 \mathrm{p})\end{array}$ & $\begin{array}{l}37.80 \pm 15.12 / \\
(50.30 \pm 25.15) \\
\end{array}$ \\
\hline 12 & $\begin{array}{l}\text { Tincture of } \\
\text { Sophora japonica }\end{array}$ & $2.05 \pm 0.05$ & $3.95 / 50$ & 0.079 & $\begin{array}{l}50 \pm 20 / \\
(1-2 p) \\
\end{array}$ & $\begin{array}{l}3.95 \pm 1.58 / \\
(3.95 \div 7.90) \\
\end{array}$ \\
\hline 13 & $\begin{array}{l}\text { Tincture of } \\
\text { eucalyptus }\end{array}$ & $1.50 \pm 0.05$ & $2.05 / 25$ & 0.082 & $\begin{array}{l}50 \pm 20 / \\
(2 \pm 1 p)\end{array}$ & $\begin{array}{l}4.10 \pm 1.64 / \\
(4.10 \pm 2.05) \\
\end{array}$ \\
\hline 14 & $\begin{array}{l}\text { Tincture of } \\
\text { propolis }\end{array}$ & $1.20 \pm 0.05$ & $7.00 / 25$ & 0.280 & $\begin{array}{l}50 \pm 20 / \\
(2 \pm 1 \mathrm{p}) \\
\end{array}$ & $\begin{array}{c}14.00 \pm 5.60 / \\
(14.00 \pm 7.00)\end{array}$ \\
\hline 15 & $\begin{array}{l}\text { Tincture of } \\
\text { calendula }\end{array}$ & $1.29 \pm 0.05$ & $2.90 / 40$ & 0.073 & $\begin{array}{c}50 \pm 20 / \\
(2 p)\end{array}$ & $\begin{array}{c}3.65 \pm 1.46 / \\
(5.80)\end{array}$ \\
\hline
\end{tabular}

As it can be seen from Table, almost all medicines are within the range of weak to medium value of the complex indicator of the antimicrobial activity (between 1.0 and 2.5). It is also worth mentioning that some medicines can be left in significant amount during the course of treatment (for instance, "Metrogyl Denta", "Hexoral", "Chlorophillipt" and "Fitodent"); that is why it is possible to recommend manufacturers to reduce the pack volume.

For pharmacoeconomic analysis two main indicators characterizing a medicine have been taken from Table. They are its comp- lex indicator of the antimicrobial activity (pharmacological constituent) and cost of the course of treatment in entire packs (economic constituent) in hryvnia (UAH). Aiming to ordering of pharmacoeconomic indicators of the medicines studied it has been suggested to take the ratio of the treatment course cost in entire packs and the complex indicator of the drug antimicrobial activity. This indicator shows the drug cost per unit of the complex indicator of the drug antimicrobial activity while using. From the consumer's viewpoint, the lower this ratio is, the more beneficial it is for him. There- fore, in Fig. 1 below this indicator is presented in decreasing order for medicines under research.

As it can be seen from Fig. 1, all medicines under research can be divided approximately into 4 groups. For the purpose of more visual presentation of drug distribution according to their complex indicator of the antimicrobial activity (which measurement error is taken at the level of 5\%) and cost of the course of treatment (which measurement error is taken at the level of $50 \%$ ) the data from Table is shown in Fig. 2.

As it can be seen from Fig. 2, the medicines under research are 


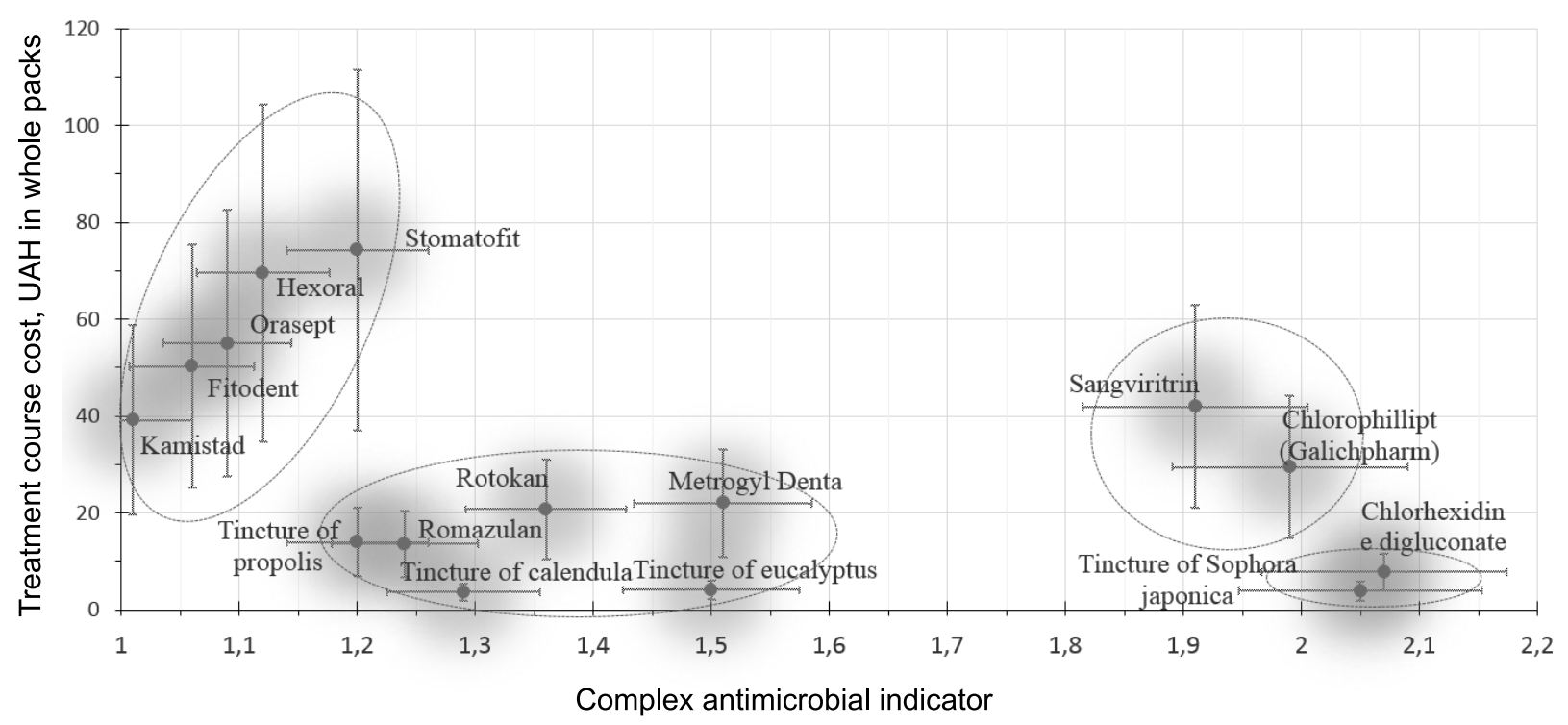

Fig. 2. Distribution of the medicines studied according to the treatment course cost and the complex antimicrobial indicator

easily categorized into 5 main groups. The following medicines fall into the group of the best indicators (the maximum value of the complex indicator of the antimicrobial activity with the minimum cost of the course of treatmentamong the medicines studied): the tincture of Sophora japonica and chlorhexidine digluconate, although their values of the complex indicator of the antimicrobial activity are in the zone of the medium activity.

Then, there is a group of new galenical medicines - "Sangviritrin" and "Chlorophillipt" (Galichpharm), which are slightly inferior in their antimicrobial activity and require increased expenditures on treatment on the part of the consumer.

They are followed by medicines from the third group - "Metrogyl Denta" and the tincture of eucalyptus, which demonstrate antimicrobial properties of the medium potency with acceptable cost for the course of treatment.

The forth group of medicines "Rotokan", "Romazulan", the tincture of propolis and the tincture of calendula - have satisfactory antimicrobial properties with the acceptable cost for the course of treatment.

Finally, medicines of the fifth group - "Stomatofit", "Hexoral", "Orasept", "Kamistad" and "Fitodent" - appeared to be the most expensive and poorly efficient.

\section{CONCLUSIONS}

In this paper the pharmacoeconomic analysis of 15 antimicrobial medicines used in dentistry has been conducted. For this purpose the valuation method of antimicrobial properties of medicines on the basis of vector algebra has been suggested and applied; it allowed calculating a complex indicator of the drug antimicrobial activity for quantitative estimation of the pharmacological effect.

It has been shown that the tincture of Sophora japonica and the solution of chlorhexidine digluconate have the best indicators of antimicrobial properties and the lowest treatment cost among the medicines studied at the level of 5-10 UAH. The second group of medicines - "Sanguiritrin" and "Chlorophillipt" (Galychpharm) is as good as the first one in terms of antimicrobial properties, but the course of treatment with these medicines costs up to 30-40 UAH. The third group of medicines "Metrogyl Denta", the tincture of eucalyptus - exhibits antimicrobial properties of a medium potency and their cost for the treatment course is in the range of 10 20 UAH. The forth group of medicines - "Rotokan", "Romazulan”, the tincture of calendula and the tincture of propolis - exhibits the weak antimicrobial properties and has a relatively low cost of treatment in the range of 5-20 UAH. The fifth group of medicines - "Stomatofit", "Orasept", "Hexoral", "Fitodent", and "Kamistad" - exhibits the weakest antimicrobial properties and has the most expensive course of treatment in the range of 40-80 UAH.

It has been noted that some of the medicines studied (for instance, "Metrogyl Denta", "Hexoral", "Chlorophillipt" and "Fitodent") have impractical volume since up to half of the pack is left after finishing the course of treatment. Therefore, we can recommend manufacturers to reduce the drug quantity in the pack by $30-50 \%$ for consumer's convenience. 


\title{
REFERENCES
}

1. Волянський Ю.Л., Грищенко І.С., Широкобоков В.П. та ін. Вивчення специфічної активності антимікробних лікарських засобів: Метод. рекоменд. - К., 2004. - 38 c.

2. Волянський Ю.Л., Бірюкова С.В., Гриценко І.С. та ін. Вивчення специфічної активності антимікробних лікарських засобів. - Х., 2004. - 38 c.

3. Державна фармакопея України / Державне підприємство «Науково-експертний фармакопейний центр». - 1-е вид. - Х.: РІРЕГ, 2001. - Доп. 1. - 2004. - 520 с.

4. Компендиум 2005 - лекарственные препараты / Под ред. В.Н.Коваленко, А.П.Викторова. - К.: МОРИОН, 2005. - 1920 с.

5. Основные методы лабораторных исследований в клинической бактериологии / Под ред. ВОЗ. Женева, 1994. - 131 с.

6. Albandar J.M., Rams T.E. // Periodontol. 2000. - 2002. - Vol. 29. - P. 7-10.

7. Axelsson P., Albandar J.M., Rams T.E. // Periodontol. 2000. - 2002. - Vol. 29. - P. 235-246.

8. Bascones Martinez A., Figuero Ruiz E. // Av. Periodontol. Implantol. - 2005. - Vol. 17, №3. - P. 111-118.

9. Cobb Charles M. // The J. of Dental Hygiene. - 2008. - Vol. 83, №6. - P. 4-9.

10. John G. Meechan, Robin Seymour Drug Dictionary for Dentistry. 1-st ed. - Publisher: Oxford University Press, USA. 2002. - 444 p.

11. Nishihara T., T. Koseki // Periodontol. 2000. - 2004. - №36. - P. 14-26.

12. Position Paper Guidelines for Periodontal Therapy //J. of Periodontol. - 2001. - Vol. 72, №11. - P. 1624-1628.

13. Quirynen M., Teughels W., De Soete M., van Steenberghe D. // Periodontol. 2000. - 2002. - Vol. 28. - P. 72-90.

14. Slots J. // J. Periodontal Res. - 2002. - Vol. 37. - P. 389-398.

15. Slots J., Jorgensen M.G. // Periodontol. 2000. - 2002. - Vol. 28. - P. 298-312.

16. Walker C.B., Karpinia K., Baehli P. // Periodontol. 2000. - 2004. - Vol. 36. - P. 146-165.

\section{ФАРМАКОЕКОНОМІЧНИЙ АНАЛІЗ СТОМАТОЛОГІЧНИХ АНТИБАКТЕРІАЛЬНИХ ПРЕПАРАТІВ}

М.М.Бойко, О.І.Зайцев, Л.В.Нефьодова, Л.В.Яковлєва

Національний фармацевтичний університет

Ключові слова: фармакоекономічний аналіз; синтетичні і природні стоматологічні препарати

\begin{abstract}
Представлений фармакоекономічний аналіз 15 антимікробних препаратів, які застосовуються в стоматології. Для цього був запропонований і використаний метод оцінки антимікробних властивостей препаратів на основі векторної алгебри, який дозволив розрахувати комплексний показник антимікробної активності препарату для кількісної оцінки фармакологічного ефекту. Показано, що «Настойка софори японської» і розчин «Хлоргексидину біглюконат» володіють найкращими показниками антимікробної властивості і мають найменшу вартість лікування у порівнянні з іншими досліджуваними препаратами на рівні 5-10 грн. Першій групі не поступається за антимікробними властивостями друга група препаратів: «Сангвіритрин» $i$ «Хлорофіліпт» (Галичфарм), проте вартість курсу лікування цими препаратами досягає 30-40 грн. Третя група препаратів «Метрогіл Дента», «Настойка евкаліпту» проявляє середньої сили антимікробні властивості, і вартість лікування ними складає в межах 10-20 грн. Препарати четвертої групи «Ротокан», «Ромазулан», «Настойка календули», «Настойка прополісу» мають слабкі антимікробні властивості, але відносно низьку вартість курсу лікування - від 5 до 20 грн. П’ята група препаратів «Стоматофіт», «Орасепт», «Гексорал», «Фітодент», «Камістад» виявляє найслабші антимікробні властивості і відрізняється найдорожчим курсом лікування в межах 40-80 грн. Відзначено, що деякі досліджувані препарати (наприклад, «Метрогіл Дента», «Гексорал», «Хлорофіліпт», «Фітодент») мають нераціональний об'єм, оскільки залишається до половини упаковки після проходження курсу лікування. Тому можна рекомендувати виробникам зменшити кількість препарату в упаковці на 30-50\% для зручності споживача.
\end{abstract}

\section{ФАРМАКОЭКОНОМИЧЕСКИЙ АНАЛИЗ СТОМАТОЛОГИЧЕСКИХ АНТИБАКТЕРИАЛЬНЫХ ПРЕПАРАТОВ Н.Н.Бойко, А.И.Зайцев, Л.В.Нефёдова, Л.В.Яковлева Национальный фармацевтический университет}

Ключевые слова: фармакоэкономический анализ; синтетические и природные стоматологические препараты

Представлен фармакоэкономический анализ 15 антимикробных препаратов, которые применяются в стоматологии. Для этого был предложен и использован метод оценки антимикробных свойств препаратов на основе векторной алгебры, который позволил рассчитать комплексный показатель антимикробной активности препарата для количественной оценки фармакологического эффекта. Показано, что «Настойка софоры японской» и раствор «Хлоргексидина биглюконата» обладают наилучшими показателями антимикробных свойств и наименьшей стоимостью лечения из всех исследуемых препаратов на уровне 5-10 грн. Первой группе не усту- 
пает по антимикробным свойствам вторая группа препаратов: «Сангвиритрин» и «Хлорофиллипт» (Галичфарм), однако стоимость курса лечения этими препаратами достигает 30-40 грн. Третья группа препаратов «Метрогил Дента», «Настойка эвкалипта» проявляет средней силы антимикробные свойства, и стоимость лечения ими составляет в пределах 10-20 грн. Препараты четвертой группы "Ротокан», «Ромазулан», «Настойка календулы», «Настойка прополиса» имеют слабые антимикробные свойства, но относительно низкую стоимость курса лечения - от 5 до 20 грн. Пятая группа препаратов «Стоматофит», «Орасепт», «Гексорал», "Фитодент», «Камистад» проявляет самые слабые антимикробные свойства и имеет самую высокую стоимость курса лечения в пределах 40-80 грн. Отмечено, что некоторые исследуемые препараты (например, «Метрогил Дента», «Гексорал», «Хлорофиллипт», «Фитодент») имеют нерациональный объем, поскольку остается до половины упаковки после прохождения курса лечения. Поэтому можно рекомендовать производителям уменьшить количество препарата в упаковке на 30-50\% для удобства потребителя.

Address for correspondence:

Received in 20.12.2013

18, 0. Nevsky str., Kharkiv, 61140, Ukraine.

Tel. (57) 771-81-52. E-mail: Boykoniknik@gmail.com.

National University of Pharmacy 